\title{
Canadian and international winners of major health research prizes, 1959-2018
}

\author{
Robert J. Redelmeier, C. David Naylor MD DPhil
}

— Cite as: CMAJ 2018 November 12;190:E1328-31. doi: 10.1503/cmaj.181056

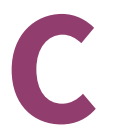

ommon indicators of excellence in biomedical and health research include publications in top-tier journals, citations per publication, measurable impacts of research on practice or policy-making, and major prizes for extraordinary research accomplishments. ${ }^{1}$ Among major medical research prizes, the best known is the Nobel Prize in Physiology or Medicine, along with the Nobel Prize in Chemistry (often awarded to bioscientists). Other globally prominent awards are sometimes seen as "pre-Nobels," and awarding organizations even advertise their record of early recognition of scientists who go on to win the Nobel Prize, especially as these scientists tend to be awarded after the importance of discoveries has withstood the test of time. ${ }^{2}$

Canada hosts one prize that falls into this category - the Canada Gairdner International Awards, initiated in 1959 (hereafter, "Gairdner") (Box 1). Others include the Albert Lasker Basic Medical Research Award ("Lasker Basic"); the Lasker-DeBakey Clinical Medical Research Award ("Lasker Clinical”); and the Louisa Gross Horwitz Prize ("Horwitz"). Each of these awards has a distinguished history, rigorous selection criteria and worldwide scope. ${ }^{1}$ An apparent recent decline in the number of Canadian-based Gairdner awardees has fuelled speculation about the importance and causes of this trend. We tracked proportions of Canadianbased and international Gairdner awardees, and their success in winning other major research prizes, to establish how Canadian biomedical and health scientists are doing on the global stage.

\section{The arithmetic of excellence}

We assembled lists of Gairdner awardees (1959 to the present), and tracked them forward and back to ascertain which of them also won a Nobel Prize (Physiology or Medicine, or Chemistry, back to 1900), a Lasker Clinical or Basic (1946), or a Horwitz (1967). Each individual recipient for the time span from 1959 onward was screened to ascertain connections to Canada, such as place of birth and location of postsecondary education (undergraduate, graduate or medical degree). However, the key factor in attribution was whether the prize-worthy research was done in Canada. Sources included websites of the relevant prizegiving agencies or foundations, and a wide variety of online publications (e.g., obituaries, biographies, award citations and institutional materials), and direct contact with the Gairdner Foundation and awardees themselves.

\section{KEY POINTS}

- The proportion of Canadian-based winners of Canada Gairdner International Awards has declined significantly since the inception of the award in 1959.

- The numbers of Canadian-based winners receiving any other major prize has been consistently low ( $11 \%$ overall) as compared with international winners (50\%), with an even larger gap for Nobel prizes.

- There were no significant changes over time in the proportions of international or Canadian-based Gairdner laureates who went on to win other prizes.

- These findings cannot be explained by a decline in the quality of Canadian-based research, suboptimal nomination efforts or biased adjudication; rather, the most likely explanation of these findings is a more rigorous global selection process as the Gairdner prize matured.

- Uneven government support and skewed priority-setting by federal funders cannot be ruled out as factors.

For awards made in the same year, we assigned temporal precedence to the Gairdner. The Horwitz and Lasker awards are announced in the fall of each year, generally a few weeks ahead of the Nobel announcements, which occur by tradition in the first or second week of October. The Gairdner announcements have varied in timing, and are now made in April or May. However, the review processes have always predated the other awards' announcements and been undertaken independently. ${ }^{3}$

We grouped prize winners into six time intervals: 1959-1969, 19701979, 1980-1989, 1990-1999, 2000-2009 and 2010-2018. Our primary analysis was prespecified as comparing the proportions of international and Canadian-based awardees who won one or more major prizes other than the Gairdner, and whether that occurred before or after the Gairdner was awarded. We undertook a secondary analysis focusing specifically on Nobel Prizes won by Gairdner laureates.

These analyses make no allowance for differences in the number of additional prizes won. Those differences between Canadian and international winners were examined on an exploratory basis.

For six individuals who won two Gairdners, we treated each award as a separate instance; the same was done when those multiple winners became repeat winners of other prizes. This required matching each Gairdner award with any other major prize that preceded or followed it, as shown in Table 1. 
Box 1: A brief history of the Gairdner award and selection process ${ }^{3}$

At the outset in 1959, the Gairdner award selection process involved a group of University of Toronto academics tasked with recognizing contributions to "rheumatic and cardiovascular diseases." The scope was broadened to "any branch of medicine" in 1962. With the wider mandate, a two-tiered process was initiated, which continues today. A Canadian-based medical review panel assesses scores of nominations and produces a short list from which awardees are chosen by a medical advisory board.

The first medical advisory board member from outside Ontario was added in 1974, and it was not until 1991 that the first international member was appointed. From then on, the medical advisory board gradually evolved into a more international body, typically including Nobel laureates and other winners of major prizes, along with leaders of major medical faculties from the United Kingdom and the United States. This transformation was completed in 2008 when the Government of Canada granted \$20 million as an endowment to help the Gairdner Foundation enhance its international profile, support educational outreach across Canada, and ensure that up to seven awards could be given each year, as described below.

The number of awardees in the first three decades ranged typically from five to seven per year, and rose as high as nine each decade. Numbers fell slightly in the 1990s, a decade of fiscal restraint; one year saw only three awards made. Since 2000, five awards per annum has been the norm, with minimal variation, except for 2002 when 10 awards were given to celebrate the sequencing of the human genome.

For this analysis, we excluded the Canada Gairdner Wightman Award (initiated in 1976, recognizing excellence and leadership exclusively among Canadian researchers) and the more recent (2009) John Dirks Canada Gairdner Global Health Award.

Details of our statistical analysis are presented in Appendix 1 (available at www.cmaj.ca/lookup/suppl/doi:10.1503/cmaj.181056/-/DC1).

There were 349 Gairdner awards made from 1959 to 2018, 47 to Canadian-based researchers and 302 to international researchers. Table 2 shows the respective numbers and proportions of researchers who won Gairdner and other awards across the six periods. The proportion of Canadian-based Gairdner awardees in the first three decades was markedly higher than the most recent three decades $(p=0.009)$, with a declining proportion of Canadian versus other awardees over time based on a test for trend $(p=0.004)$.

\section{Competing explanations}

This decline is meaningfully larger than would be expected by chance alone. Therefore, it is reasonable to ask why it has occurred.

One theory is that Canada enjoyed a golden age of medical research decades ago but has lost ground relative to other nations owing to changes over the last 30 years in the organization and generosity of federal research funding ("paradise lost"). A competing and wider-ranging explanation is that Canadians have simply not been aggressive enough at promoting our best and brightest researchers for prestigious international awards ("misplaced modesty"). The prevalence of this perception is reflected in the initiation in 2013 of a national Canvassing Committee to Enhance Global Recognition for Canadian Research Excellence, operating under the auspices of the Governor General of Canada. ${ }^{4,5}$
In contrast, we hypothesized that the Gairdner award initially had a modest bias in favour of local talent (a "home-ice edge") but has grown in stature and now has an adjudication process that combs the global field of medical research in a fashion similar to other major prizes. The Gairdner Foundation itself has explicitly rejected this possibility. A 1999 monograph celebrating the 40th anniversary of the awards asserts, "Though a local foundation might be thought to favour Canadians, there is no evidence that the Gairdner has ever done so. Nor has there ever been a 'quota.' The Canadians who have won in recent years have been outstanding scientists, and several have gone on to win other awards internationally, most notably Michael Smith, who won the Nobel Prize in Chemistry in 1993."3

As this last assertion implies, an obvious way to test assumptions about quality of awardees is through convergent and divergent validation. For example, in earlier years, were Canadian Gairdner awardees winning other pinnacle prizes at the same rate as international colleagues? A much lower rate would imply an early selection bias favouring Canadian work, particularly if that difference persisted even as the proportion of Canadian-based winners fell. Conversely, if the proportion of international winners of multiple prizes was consistently higher, it would argue strongly against the possibility that meritorious Canadian-based work was being overlooked in nomination and adjudication processes.

\section{Is quality declining?}

As Table 2 shows, only 5 of 47 (11\%) Canadian-based winners ever received another international pinnacle prize, compared with 152 of $302(50 \%)$ international winners $(p<0.001)$. Of the 152, 77 were multiple winners, leading to a total of 255 major prizes other than a Gairdner, whereas the Canadian-based researchers each won a single additional prize. The five were Michael Smith (Nobel 1993), James Till (Lasker Basic 2005), Ernest McCulloch (Lasker Basic 2005), Yoshio Masui (Lasker Basic 1998) and Anthony Pawson (Horwitz 2004). The proportion of Gairdner winners working in Canada who won a Nobel Prize (Table 3) was also lower: 1 of 47 versus 89 of 302 international winners or, excluding prior Nobels, 85 of 302 ( $p<0.001$ for both).

There were no significant changes over the six decades in the proportions of additional prize winners for international ( $p=0.7)$ or Canadian-based $(p=0.8)$ Gairdner awardees. The putative "golden age" from 1959 to 1989 saw 3 of 35 (9\%) Canadian-based awardees win again, as opposed to 2 of $12(17 \%)$ in the next three decades. None of these findings are suggestive of a change in quality in either group. No work done in Canada was recognized with another pinnacle prize before the Gairdner, as contrasted with 45 international winners who won 56 major awards ( $p<0.001$ for both) in the preceding years or same year. Although $p$ values moved modestly, the overall results were robust after excluding prior winners.

\section{What are the lessons for Canada?}

The Gairdner prize arguably represents Canada's most prestigious award for research in any discipline. Our analysis of available data confirms that the number of Canadian-based scientists winning Gairdner awards has declined significantly in recent decades, but offers no 
support for nostalgic narratives of a research "paradise lost" or arguments that Canadians have not been nominated in adequate numbers or disadvantaged by the adjudication process in recent years.

As to "misplaced modesty," making more and stronger nominations for research prizes is a positive measure. However, it takes decades for first-tier scientists to scale the peaks of research accomplishment, their milestones are highly visible, and many Canadian institutions routinely nominate their top performers for major prizes. Even an argument that Canada has lost ground owing to intensifying global competition seems suspect when one examines the countries where Gairdner awardees worked. The traditional powerhouses the US, the UK, Japan and Germany - still dominate these awards.
Indeed, the patterns observed here are most consistent with the "home-ice edge" hypothesis - a modest bias in favour of Canadian researchers that attenuated as the Gairdner award matured into a prestigious prize with a high global profile. Positing early domestic sympathies is not intended as criticism: the visionaries who set the Gairdner machinery in motion almost six decades ago recognized outstanding researchers from around the world from the outset. Within a few years they had also established their prescience by repeatedly celebrating researchers who went on to win other pinnacle prizes. However, given the history of the Gairdner award, as outlined in Box 1, it is not surprising that Canadian content has become less prominent on the Gairdner channel than was the case in earlier decades.

Table 1: Further awards and attribution for winners of multiple Gairdner awards

\begin{tabular}{|c|c|c|c|c|}
\hline Name & First Gairdner & Related awards* & Second Gairdner & Related awards \\
\hline Seymour Benzer & $\begin{array}{l}1964-\text { "elucidation of the fine structure of } \\
\text { genes" (pioneered phage-based methods) }\end{array}$ & $\begin{array}{l}1971 \text { Lasker Basic } \\
1976 \text { Horwitz }\end{array}$ & $\begin{array}{l}2004 \text { - "myriad contributions to } \\
\text { neurogenetics" }\end{array}$ & None \\
\hline Frederick Sanger & $\begin{array}{l}1971 \text { - advances in protein biochemistry, } \\
\text { specifically elucidating the structure of } \\
\text { insulin }\end{array}$ & 1958 Nobel & $\begin{array}{l}1979 \text { - sequencing nucleic acids } \\
\text { (RNA, DNA) }\end{array}$ & $\begin{array}{l}1979 \text { Lasker Basic } \\
1979 \text { Horwitz } \\
1980 \text { Nobel }\end{array}$ \\
\hline Sydney Brenner & $\begin{array}{l}1978 \text { - contributions "to the understanding } \\
\text { of how genetic information is read and } \\
\text { translated" (messenger RNA) }\end{array}$ & 1971 Lasker Basic & $\begin{array}{l}1991 \text { - “... establishing C. elegans as } \\
\text { a model for studying genetic control } \\
\text { of development" }\end{array}$ & 2002 Nobel \\
\hline Oliver Smithies & $\begin{array}{l}1990 \text { - "gel electrophoresis methods that } \\
\text { allow the separation and identification of } \\
\text { specific proteins and nucleic acids" } \dagger\end{array}$ & None & $\begin{array}{l}1993 \text { - "homologous recombination } \\
\text { to generate targeted mutations" (i.e., } \\
\text { gene targeting and knockout mice) }\end{array}$ & $\begin{array}{l}2001 \text { Lasker Basic } \\
2007 \text { Nobel }\end{array}$ \\
\hline Francis Collins & $\begin{array}{l}1990 \text { - "identification of the gene for } \\
\text { cystic fibrosis" }\end{array}$ & None & $\begin{array}{l}2002 \text { - part of a group of } 10 \text { awardees } \\
\text { celebrating "the sequencing of the } \\
\text { human and other genomes" }\end{array}$ & None \\
\hline
\end{tabular}

Table 2: Canadian and international Gairdner awardees, and other major prizes won before or after by awardees in the relevant period, no. (\%)

\begin{tabular}{|c|c|c|c|c|c|c|c|c|}
\hline Period & $\begin{array}{c}\text { No. of } \\
\text { awards }\end{array}$ & $\begin{array}{c}\text { Total } \\
\text { Canadian } \\
\text { awardees }\end{array}$ & $\begin{array}{c}\text { Total } \\
\text { international } \\
\text { awardees }\end{array}$ & $\begin{array}{c}\text { Canadian } \\
\text { awardees of } \\
\text { one or more } \\
\text { other key } \\
\text { prizes }\end{array}$ & $\begin{array}{l}\text { International } \\
\text { awardees of } \\
\text { one or more } \\
\text { other key } \\
\text { prizes }\end{array}$ & $\begin{array}{c}\text { One other } \\
\text { prize: } \\
\text { Canadian/ } \\
\text { international }\end{array}$ & $\begin{array}{c}\text { Two other } \\
\text { prizes: } \\
\text { international } \\
\text { only }\end{array}$ & $\begin{array}{l}\text { Three other } \\
\text { prizes: } \\
\text { international } \\
\text { only }\end{array}$ \\
\hline 1959-1969 & 69 & $\begin{array}{c}13 \\
(18.8)\end{array}$ & $\begin{array}{c}56 \\
(81.2)\end{array}$ & $\begin{array}{c}2 \\
(15.4)\end{array}$ & $\begin{array}{c}21 \\
(37.5)\end{array}$ & $\begin{array}{c}2 / 13 \\
(15.4 / 23.2)\end{array}$ & $\begin{array}{c}6 \\
(10.7)\end{array}$ & $\begin{array}{c}2 \\
(3.6)\end{array}$ \\
\hline 1980-1989 & 68 & $\begin{array}{c}11 \\
(16.2)\end{array}$ & $\begin{array}{c}57 \\
(83.8)\end{array}$ & $\begin{array}{c}1 \\
(9.1)\end{array}$ & $\begin{array}{c}35 \\
(61.4)\end{array}$ & $\begin{array}{c}1 / 10 \\
(9.1 / 17.5)\end{array}$ & $\begin{array}{c}13 \\
(22.8)\end{array}$ & $\begin{array}{c}12 \\
(21.1)\end{array}$ \\
\hline 1990-1999 & 50 & $\begin{array}{c}6 \\
(12.0)\end{array}$ & $\begin{array}{c}44 \\
(88.0)\end{array}$ & $\begin{array}{c}2 \\
(33.3)\end{array}$ & $\begin{array}{c}26 \\
59.1\end{array}$ & $\begin{array}{c}2 / 9 \\
(33.3 / 20.5)\end{array}$ & $\begin{array}{c}10 \\
(22.7)\end{array}$ & $\begin{array}{c}7 \\
(15.9)\end{array}$ \\
\hline 2000-2009 & 55 & $\begin{array}{c}5 \\
(9.1)\end{array}$ & $\begin{array}{c}50 \\
(90.9)\end{array}$ & $\begin{array}{c}0 \\
(0.0)\end{array}$ & $\begin{array}{c}26 \\
(52.0)\end{array}$ & $\begin{array}{c}0 / 14 \\
(0.0 / 28.0)\end{array}$ & $\begin{array}{c}11 \\
(22.0)\end{array}$ & $\begin{array}{c}1 \\
(2.0)\end{array}$ \\
\hline Total & 349 & 47 & 302 & 5 & 152 & $5 / 75$ & 51 & 26 \\
\hline
\end{tabular}


Table 3: Nobel Prizes won by Gairdner awardees, at any time, or only after a Gairdner award, no. (\%)

\begin{tabular}{|c|c|c|c|c|}
\hline \multirow[b]{2}{*}{ Period } & \multicolumn{2}{|c|}{ Before and after } & \multicolumn{2}{|c|}{ After* } \\
\hline & Canadian-based & International & Canadian-based & International \\
\hline 1959-1969 & $\begin{array}{l}0 / 13 \\
(0.0)\end{array}$ & $\begin{array}{l}11 / 56 \\
(19.6)\end{array}$ & $\begin{array}{l}0 / 13 \\
(0.0)\end{array}$ & $\begin{array}{l}11 / 56 \\
(19.6)\end{array}$ \\
\hline 1970-1979 & $\begin{array}{l}0 / 11 \\
(0.0)\end{array}$ & $\begin{array}{l}17 / 51 \\
(33.3)\end{array}$ & $\begin{array}{l}0 / 11 \\
(0.0)\end{array}$ & $\begin{array}{l}16 / 51 \\
(31.4)\end{array}$ \\
\hline 1980-1989 & $\begin{array}{l}1 / 11 \\
(9.1)\end{array}$ & $\begin{array}{l}26 / 57 \\
(45.6)\end{array}$ & $\begin{array}{l}1 / 11 \\
(9.1)\end{array}$ & $\begin{array}{l}25 / 57 \\
(43.9)\end{array}$ \\
\hline 1990-1999 & $\begin{array}{c}0 / 6 \\
(0.0)\end{array}$ & $\begin{array}{l}19 / 44 \\
(43.2)\end{array}$ & $\begin{array}{c}0 / 6 \\
(0.0)\end{array}$ & $\begin{array}{l}18 / 44 \\
(40.9)\end{array}$ \\
\hline 2000-2009 & $\begin{array}{c}0 / 5 \\
(0.0)\end{array}$ & $\begin{array}{l}11 / 50 \\
(22.0)\end{array}$ & $\begin{array}{c}0 / 5 \\
(0.0)\end{array}$ & $\begin{array}{l}10 / 50 \\
(20.0)\end{array}$ \\
\hline 2010-2018 & $\begin{array}{c}0 / 1 \\
(0.0)\end{array}$ & $\begin{array}{c}5 / 44 \\
(11.4)\end{array}$ & $\begin{array}{c}0 / 1 \\
(0.0)\end{array}$ & $\begin{array}{c}5 / 44 \\
(11.4)\end{array}$ \\
\hline Totals & $1 / 47$ & $89 / 302$ & $1 / 47$ & $85 / 302$ \\
\hline \multicolumn{5}{|c|}{$\begin{array}{l}\text { `Excludes Satoshi Ōmura, who won the John Dirks Canada Gairdner Global Health Award in } 2014 \text { and a Nobel Prize in 2015. His inclusion brings the total post-Gairdner Nobel } \\
\text { laureates to } 87 \text {, per the foundation's website. The four prior Nobels were James Watson, Fred Sanger, Har Gobind Khorana and Arthur Kornberg. Watson (Gairdner 2002) } \\
\text { received his award as part of a special set of } 10 \text { to celebrate the completion of the sequencing of the human genome. He received a Lasker Basic Research Award with Francis } \\
\text { Crick and M.H.F. Wilkins in } 1960 \text {, but only Crick received a Gairdner in 1962, the same year the trio received a Nobel Prize. Arthur Kornberg (Gairdner 1995) shared a Nobel Prize } \\
\text { with Severo Ochoa in } 1959 \text { for elucidating methods for synthesis of RNA and DNA. His Gairdner prize recognized his ongoing work on DNA replication. Har Gobind Khorana } \\
\text { (Gairdner 1980) shared the Nobel Prize with Marshall Nirenberg and Robert Holley in } 1968 \text { for contributions to elucidating the role of nucleic acids in transmitting genetic } \\
\text { information. In the same year, they received both a Horwitz and Lasker Basic, but only Nirenberg received a Gairdner (1967). Khorana's first post as an independent investigator } \\
\text { was in } 1952 \text { at the British Columbia Research Council; The University of British Columbia's Michael Smith, the sole Canadian-based Nobel laureate in biomedical research in } \\
\text { recent decades, was a postdoctoral fellow with Khorana. Although Khorana's Nobel-related work began during that period, the key breakthroughs occurred after he moved to } \\
\text { the University of Wisconsin-Madison in 1960. Khorana continued to innovate for years, making contributions that anticipated polymerase chain reaction and, as his Gairdner } \\
\text { citation states, "chemical synthesis of a functional gene." Frederick Sanger (Gairdner 1971) received a Nobel Prize in } 1958 \text { for breakthroughs related to insulin and } \\
\text { macromolecule synthesis. He won a second Gairdner in 1979, followed by a Lasker Basic and Horwitz in } 1979 \text { for his work on DNA sequencing. }\end{array}$} \\
\hline
\end{tabular}

Although funding patterns are therefore unlikely to be the sole explanation for this decline, it would be wrong-headed to assume they are immaterial to Canada's current underperformance. Federal support for independent health research was cut in the 1990s as the Government of Canada fought to reduce high levels of national indebtedness. It grew dramatically as the Canadian Institutes of Health Research (CIHR) was launched, and then fell again in the years when the Harper government capped extramural research funding and prioritized investment in applied and innovation-facing research. ${ }^{6}$ This instability in funding levels and priorities is not conducive to the sustained excellence in original investigation that leads to major prizes.

What conclusions can be drawn from these findings regarding the future of health research in Canada? One interpretation is that Canada is simply too small to compete and win international prizes on the global playing field, and should not be investing heavily in independent health research. The comparative performance of many other small countries that invest more generously and manage their publicly financed research more effectively would suggest that this is an unduly pessimistic and defeatist approach. ${ }^{6}$ If, as documented, there has never been a golden age of Canadian medical research, then surely the best response is to ask, Why not seek to start a golden age now, at a time when the relevance of basic and applied health research has never been clearer? In response to the 2017 report of Canada's Fundamental Science Review, ${ }^{6}$ very positive steps in this direction were taken in the 2018 federal budget. However, further investments, a stable funding trajectory, and improved governance of research agencies are all needed in the years ahead for Canada's health researchers to achieve their full potential.

\section{References}

1. Naylor CD, Bell JI. On the recognition of global excellence in medical research. JAMA 2015;314:1125-6.

2. Redelmeier RJ, Naylor CD. Changes in characteristics and time to recognition of medical scientists awarded a Nobel Prize. JAMA 2016;316:2043-4.

3. Hulse E, Dirks JH. The Gairdner Foundation: a celebration. 1st ed. Toronto: The Gairdner Foundation; 1999.

4. Canvassing Committee to Enhance Global Recognition for Canadian Research Excellence. Ottawa: Innovation, Science and Economic Development Canada; (modified 2018 July 18). Available: http://science.gc.ca/eic/site/063.nsf/eng/h_ CE4ADF35.html (accessed 2018 Aug. 4).

5. Charbonneau L. A plan to double the number of Canadians winning international awards [margin notes]. Ottawa: University Affairs; 2014. Available: www. universityaffairs.ca/opinion/margin-notes/plan-double-number-canadians -winning-international-awards (accessed 2018 Aug. 9).

6. Naylor CD, Birgeneau RJ, Crago M, et al.; Secretariat of the Advisory Panel on Federal Support for Fundamental Science. Investing in Canada's future: strengthening the foundations of Canadian research [final report]. Ottawa: Industry Canada; 2017.

\section{Competing interests: None declared.}

This article has been peer reviewed.

Affiliations: Arts and Science Program (Redelmeier), McMaster University, Hamilton, Ont.; Department of Medicine (Naylor), University of Toronto, Toronto, Ont.

Contributors: Both authors contributed substantially to the writing and revising of the manuscript, approved the final version to be published and agreed to be accountable for all aspects of the work.

Correspondence to: David Naylor, david.naylor@utoronto.ca 